\title{
POSTMODERNISME DALAM NOVEL BILANGAN FU KARYA AYU UTAMI
}

\author{
Irma Satriani \\ Fakulstas Sastra Universitas Gadjahmada \\ Bulaksumur, Caturtunggal, Kecamatan Depok Kabupaten Sleman \\ Email: satriani_irma@yahoo.com
}

\begin{abstract}
Postmodernism in Numbers Novel Fu Works Ayu Utami. Novel Numbers Fu by Ayu Utami theme spiritualism critical form of debate associated with mysticism, superstition, offerings, monotheism, and presenting intertextuality his world through myth Nyi Roro Kidul related to history Babad Tanah Jawi, myths Watugunung, and historical events contradicted by events factual. Utami represent worlds ontological pluralism Zones science fiction, fantastic fiction, and historical realities. This is indicated postmodern fiction novel with ontological issues, so you can find strategies Utami in presenting worlds in it.
\end{abstract}

\begin{abstract}
Abstrak. Postmodernisme dalam Novel Bilangan $F u$ Karya Ayu Utami. Novel Bilangan Fu karya Ayu Utami mengangkat tema spiritualisme kritis berupa perdebatan yang berhubungan dengan mistik, takhyul, sesajen, monoteisme, serta menghadirkan intertekstualitas dunianya lewat mitos Nyi Roro Kidul terkait sejarah Babad Tanah Jawi, mitos Watugunung, dan peristiwa historis yang kontradiktif dengan peristiwa faktualnya. Utami merepresentasikan dunia-dunia pluralisme ontologis meliputi zona fiksi ilmiah, fiksi fantastik, dan realitas historis. Novel ini terindikasi fiksi pascamodern dengan permasalahan ontologis, sehingga bisa ditemukan strategi-strategi Utami dalam menghadirkan dunia-dunia di dalamnya.
\end{abstract}

Keywords: postmodernisme, dunia-dunia, Fiksi fantastik, fakta historis

Istilah postmodern tercatat pertama kali pada tahun 1870-an. Konsep ini muncul pertama kali dalam sebuah judul buku tahun 1926 dan dimunculkan kembali pada tahun 1930-an dan 1940-an. Tetapi, kajian awal dan terpisah ini baru memiliki sedikit ruang dalam literature postmodernisme yang muncul pada tahun 1960an. Postmodernisme berkembang begitu cepat dan semakin jelas pada tahun 1970-an. Tokoh kunci dalam periode ini adalah Inhab Hassan, bahkan kajiannya sekarang dipandang sebagai sesuatu yang sangat bersejarah dan ungkapanungkapannya berpengaruh pada pemikiran postmodernisme kontemporer.

Teori postmodern mengembangkan wacana teori dekonstruktif yang mampu mengidentifikasi dan mengkritisi ideologi, kini bukan hanya ditemukan pada karya-karya doktriner seperti teori ekonomi atau agama borjuis namun juga dalam teks budaya pop dan iklan yang tersebar di mana-mana. Menurut pendapat Fiedler yang mengkritisi modernism dengan rasionalisme yang menyertainya dan humanism liberalnya. Dia merasakan bahwa kita mengalami kematian modernitas yang dicirikan antara lain antirasionalitas, romantisme dan sentimentalitas. Fiedler juga menekankan pentingnya hal yang lokal dan tribal sebagai wujud perlawanan terhadap esensi penekanan dan keterbatasan makna (dalam Ritzer,2009:36).

Dalam artian postmodernisme lahir karena modernism sudah dianggap tidak mampu lagi menjawab segala fenomena sosial yang terjadi di masyarakat. Hal ini bukan berarti modernisme telah mati malah postmodernisme adalah kelanjutan dari modernism. Mchael adalah salah satu dari sekian banyak pemikir dari yang berbicara mengenai postmodernisme yang sejalam dengan asumsi di atas. Menurut McHale (1991:4) postmodernisme adalah istilah yang acuannya tidak ada karena ia adalah suatu konstruksi. Lebih jauh pandangan McHale mengatakan bahwa konstruksi postmodernisme yang dibangun memiliki konsistensi diri dan koherensi internal, ruang lingkup yang tidak 
begitu luas dan tidak begitu sempit, dan produktif.

Novel Bilangan $F u$ karya Ayu Utami bercerita mengenai dongeng dan peristiwa sejarah yang berifat fantastis. Hal ini memberikan alasan untuk melakukan kajian postmodernisme. Dunia di dalam novel tersebut berpadu dengan dunia dongeng bahkan peristiwa sejarah meskipun Ayu Utami menghadirkan tokoh-tokoh fiksi yang berbeda dengan kejadian yang sebenarnya. Dalam novel ini menghadirkan pemikiran yang rasionalitas dan irasionalitas membentuk pluralitas semesta. Semesta yang pluralitas dalam novel Bilangan $F u$ dengan kehadiran dongeng, peristiwa sejarah meskipin ada kontradiksi tersebut tetap mengindikasikan postmodernisme karya. Dengan demikian, dalam novel ini akan dikaji mengenai kehadiran duniadunia dalam novel sesuai dengan konteks postmodernisme.

\section{PEMBAHASAN}

\section{Dunia-dunia}

Dalam fiksi postmodern bersifat ontologis dan menjelakan tiga dimensi yaitu dunia-dunia, kata-kata, dan konstruksi. Sehubungan dengan dunia-dunia menurut McHale ada empat cara membangun zona yaitu penjajaran (juxtaposition), penyisipan (interpolation), pelapisan (superimposition), dan misatribusi (misattribution) (1991:45). Akan tetapi, dalam novel ini hanya terdapat penyisipan dan dan pelapisan.

Zona penyisipan, yaitu penyisipan ruang asing ke dalam ruang yang lazim atau di antara ruang lazim yang berdampingan. Padahal di sana seharusnya tidak ruang antara yang merupakan interpolasi. Dalam artian pengarang akan menghadirkan zona yang disisipkan melalui teks fiksi tersebut.

Parang Jati bagaikan malaikat jatuh. Ia memiliki keluguan yang berisiko, yang muncul melalui matanya yang polos, nyaris bidadari, ketika mengajukan pertanyaanpertanyaan namun tak membumi. Tak membumi-maksudku, ia seperti tak mengenal apa yang telah menjadi praktik wajar di bumi ini. Misalnya adalah pertanyaannya mengenai pemanjatan tak bersih" yang kami lakukan. Ia seperti tidak datang dari dunia ini (Utami,2008: 37).

Pada kutipan di atas sangat jelas bahwa pengarang menyisipkan zona dunia lain (dunia tak membumi). Meski tidak secara eksplisit disebutkan ke dalam teks, tetapi sangat jelas Yuda merasakan bahwa Parang Jati bukan berasal dari dunia nyata atau bumi. Yuda membuktikan asumsinya ketika Parang Jati mengajukan pertanyaan-pertanyaan kepadanya mengenai sesuatu hal. Parang Jati selalu memiliki jawaban yang tidak terduga akan dikeluarkan kepada Yuda, sahabatnya sendiri. Bahkan Yuda menyamakan posisi Parang Jati dengan bidadari. Padahal di sisi lain Yuda sangat tahu bahwa Parang Jati memiliki rama yaitu Suhubudi yang berasal dari Watugunung.

Zona Misatributif, yaitu membangun ruang dengan cara menggantikan atribut yang telah menjadi pengetahuan umum pada suatu ruang dengan mengganti atribut baru. Intinya berupa parodi atau kritikan terhadap ruang yang ada di dunia nyata.

Kami menyebut tebing ini Batu Bernyanyi, yang kami bayangkan dari kisah Wennetou. Gunung batu yang menampakkan wajah rakasasa terlampaui purba. Ia berpunuk dan bermantelkan belukar bagai sisa surai singa jantan tua. Sisa mukanya adalah gawir yang membentuk raut dari usia tak masuk akal. Dahinya bertajuk. Hidungnya tinggi dan meleleh di kanan kiri. Dagunya rapuh, rahang yang telah kehilangan giligi. Dialah si Batu Bernyanyi bagi kami. Jika senja tiba, ia menegaskan siluetnya. Seorang Indian tua yang menyanyikan lagu-lagu menyayat hati tentang keturunan mereka yang kehilangan tanah nenek moyang. Ketika malam turun sepenuhnya, ia menghilang dalam kegelapan.Tapi jika bulan sidi seperti malam ini, dari kejauhan orang masih bisa melihat bayangannya (Utami, 2008: $17-18)$.

Dalam novel Bilangan $F u$ ini dideskripsikan bahwa Batu bernyanyi itu adalah Watugunung. Diperoleh pendeskripsian bahwa tidak mengalami kondisi yang sama seperti semula. Orang-orang desa dekat Watugunung ini banyak melakukan penambangan dan melakukan penebangan pohon secara liar bahkan pemanjat 
tebing biasa melakukan pengeboran di dasar batu sampai beberapa diameter. Hal ini tentu membuat rapuh gunung ini. Sehingga diparodikan bahwa Seorang Indian tua yang menyanyikan bahwa mereka yang telah kehilangan tanah nenek moyangnya. Serta diceritakan pula dalam novel ini bahwa, Watagunung saat ini memiliki diameter liang setara alat musik tiup. Jika stabil, siulannya rendah dan berwibawa. Jika angin meliuk-liuk, sembulan berdesis ular marah.

\section{Fiksi Postmodern X Fiksi Fantastik}

Terkait dengan fiksi postmodern yang bersifat ontologis. McHale (1991: 74) berpandangan bahwa fiksi fantastik selalu terdapat persamaan dalam setiap kasus yaitu adanya ontologi ganda (dual ontolog) di satu sisi dunia normal sehari-hari dan di sisi lain, dunia samping, dunia paranormal atau supernatural. Masing-masing ontologi tidaklah bersifat mandiri, terpisah antara yang satu dengan yang lainnya, tetapi aling berhubungan. Terdapat beberapa pola hubungan yang terbangun yaitu keragu-raguan, kebiasaan, pahlawan, dari dunia ke dunia, dan fantastik yang ditransformasikan.

Keragu-raguan berarti pengarang menghadirkan dua sekaligus dunia yang berdampingan yaitu antara dunia normal dan dunia paranormal dalam novel ini. Dalam novel Bilangan Fu ditemukan hal tersebut.

Aku mengenal salah satu lubang tebing yang menyiulkan angin. Kunamai dia sebul. Suaranya magis dan syahdu, seperti fu, alat musik tiup orang Asmat. Ini adalah yang paling berkarakter di antara lolongan angin dari lubang-lubang lain pada dinding cadas. Mereka adalah liang-liang udara, terbentuk oleh pusaran angin selama juta tahun. Berabad-abad pasukan angin menderu dan dalam ziarahnya mereka menembus gunung batu, menaburkan benih dari sebuah zaman yang jauh. Semai itu menjelma kawanan ruh anjing-anjing tebing. Setiap kali mereka bernyanyi bersahut-sahutan, imanku diteguhkan bahwa ruh anjing-anjing hutan dari masa purba itu masuh semayam di dalam gunung, untuk melantunkan lagu dari kehidupan silam. Sebul, yang melolong paling berwibawa, adalah makhluk cantik bertubuh manusia dengan kepala dan kaki serigala (Utami, 2010: 17).
Sebul yang dideskripsikan oleh Yuda dalam novel ini memiliki ciri-ciri dan tabiat seperti layaknya manusia dalamkehidupan sehari-hari. Sebul itu memiliki suara, karakter, bisa bernyanyi, punya wibawa, cantik, dan tubuhnya manusia. Akan tetapi, ditemukan pula cir-ciri dan tabiat Sebul itu berada dalam tataran paranormal dan supernatural yaitu dia bisa menyiulkan angin dan kepala dan kakinya serigala. Jika hal ini dikaitkan dengan kehidupan manusia yang norma, hal ini tidak mungkin ditemukan cirri-ciri manusia seperti ini. Namun Yuda tetap menyamakan posisi Sebul ini dengan manusia karena dia juga terkadang merasakan bahwa Sebul ini menemaninya melakukan hubungan suami istri.

Kebiasaan dikaitkan dengan penerimaan dunia paranormal dalam pengalaman biasa atau sehari-hari masyarakat.

Siang itu aku dan Parang Jati menuruni bukit, dan melihat di bawah orang-orang sedang berkumpul untuk sebuah upacara rakyat. Mestilah seorang pawang sedang menahan awan dari wilayah ini agar Sejenan bisa dilangsungkan. Upacara ini biasanya diselenggarakan menjelang musim penambangan dan pembakaran gamping rakyat yang menandai awal kemarau. Parang Jati memberitahu padaku bahwa Sejenan kali ini lebih awal daripada umumnya, sebab ini masih musim penghujan (Utami, 2008: 131).

Sajenan yang diadakan oleh penduduk desa adalah sesuatu yang biasa dilakukan di tengah-tengah mereka. Salah satu dari penduduk desa telah dipercayakan untuk melakukan Sejenan itu, Nyi Manyar. Ada beberapa hal yang menyebabkan dilakukan upcara ini dengan dilengkapi sesajen, yaitu ada perusahaan besar penambangan batu yang telah mendapat izin untuk beroperasi untuk memberi ketenangan kepada pekerjanya dari makhluk halus dan takhayul. Akan tetapi, anehnya dalam masyarakat ini, mereka lebih percaya pada teori takhayul dan itu berterima di mata masyarakat.

Perlawanan dimunculkan bisa berasal dari tokoh-tokoh yang dihadirkan pengarang ke dalam novel tersebut dan bisa muncul dari pembaca mengenai dunia normal dan paranormal. 
Sayangnya-kini aku sedikit menyesalirupanya kami tetaplah anak muda kota dengan tabiat khasnya. Kami tak menyadari bahwa rasa unggul membuat kami tuli dari dongeng-dongeng desa. Yang kami pikirkan hanyalah menaklukkan tantangan dengan memerwani tebing-tebing mustahil. Pada masa itu, tak pernah kami menggali dongeng-dongeng desa. Kami hanya bicara secukupnya dengan penduduk ketika belanja atau jajan di warung mereka. Bagi kami telur lebih menarik daripada cerita. Terlur berbentuk dan bergizi. Lagipula, mereka tak tertarik pada tebing sebagaimana kami, padahal mereka tinggal di kakinya. Kalaupun ada yang mendaki punggung gunung hingga jauh, mereka mencari kayu bakar, menebang jati, atau malah membakar kemenyan di muka sebuah pohon besar (bagaimana mereka bisa tahu itu mukanya?)

Aku tak bisa menganggap serius orangorang begini. Karena itu, sangat masuk akal jika kami tak pernah mendengar tentang misteri rangkaian kematian kambingkambing dengan simptom serangan drakula. Besar kemungkinan, salah satu di antara kami mendengarnya. Tapi ia menganggapnya sedegil sinetron televisi. Terlalu pander untuk menghabiskan energi yang dibutuhkan untuk menaklukkan gunung batu. Maka cerita itu tak pernah sampai ke telinga kam pada waktu terjadinya (Utami, 2008: 27)

Ini adalah pernyataan dari Yuda yang melakukan perlawanan terhadap dunia paranormal yang dikaitkan dengan dunia normal. Dengan alasan bahwa apa yang penduduk desa itu lakukan tidak masuk akal atau hanya bermain-main. Kematian kambing-kambing dengan simptom serangan drakula, ia tak percayai karena hal itu biasa didengarkan di televisi. Akan tetapi, masyarakat di Watugunung itu mempercayai bahwa kematian kambing itu karena serangan drakula bahkan hal ini sudah menjadi konvensi dalam masyarakat tersebut. Seperti halnya sesajen yang diletakkan oleh masyarakat di depan pohon itu, mereka sudah memiliki asumsi bahwa makhluk yang berdiam di situ tidak akan mengganggu ketenangannya.

Kisah mengenai drakula tidak bisa dilepaskan dari keadaan ini. Kisah demikian bukan tak bersadar. Sang makhluk vampire menghisap habis darah korbannya sebagai proses penyucian manusia itu dari pegetahuan duniawi. Dengan kesewenangannya, sang vampire memutuskan akah ia membirkan manusia itu mati kehabisan darah, atau memberikan kepadanya pengetahuan baru, pengetahuan yang tidak duniawi. Ia akan mempersilakan manusia meminum darahnya dalam sebuah upacara. Ia akan menaruh tubuhnya dan membiarkan si manusia mencecap di sana, ata menumpahkan daranya pada cawan dan menyodorkannya pada si manusia. Atauya, atau-jika si manusia tak mau menerima pengetahuan itu dengan suka rela, sang makhluk bisa menghancurkan darahnya melalui bekas luka gigitan secara paksa. Darah demikian dipercaya lebih asam ketimbang basa.

Kita membaca kisah-kisah drakula, yang di masa kini dianggap dongeng belaka (Utami, 2008: 64).

Lebih jauh, kutipan di atas menggambarkan perlawanan Yuda yang dijadikan pengarang mewakili zaman kekinian yang tidak mempercayai takhayul seperti drakula tersebut. Kisah-kisah seperti drakula dianggapnya sebagai dongeng saja.

Seorang lelaki berpakaian hitam-hitam mengejutkan kami. Ia mengenakan destar batik dan keluar dari belukar. Ia seperti baru selesai semadi. Kami saling mengangguk dengannya sebelum ia berjalan turun. Setelah ia hilang dari pandangan, Parang Jati mengajak ke tempat pria itu baru saja memuja. Di sana ada sebuah beringin tua yang rindang, pohon yang tahan tumbuh di bebatu. Di dekatnya ada sebuah batu besar datar bagai meja. Mezbah alam tempat persembahan dinaikkan. Di atasnya teronggok secanang sesaji dengan dupa yang masih berasap.

Parang Jati menoleh kepadaku dan menggerakkan alis dengan jahil. Ia sedikit menyeringai. Ah, baru kali ini aku melihat wajah nakalnya meski matanya masih bidadari. Parang Jati mengambil satu jeruk dan satu pisang dari sana dan menyodorkannya bagiku. Aku mengangguk-ngangguk pelan sambil menyebut anjing dalam hati. Kali ini ia menampakkan sisi lain darinya dan ganti coba menjebak aku dalam permainan tantangan. Semacam tes apakah aku percaya takhayul. Dan jika 
aku insyaf bahwa sesaji tak boleh disembarangi, apakah aku takut melanggarnya. Kesombongan urbanku tibatiba merasionalitas. Aku adalah anak akal sehat yang tak cemas pada takhayul. Hanya si bodoh yang memasang sesajen, member makan setan-setan yang tak ada (Utami, 2008: 60).

Kami menduga lelaki kehitam-hitaman tadi menolak perawatan kesehatan karena alasan mistik. Bisa jadi ia percaya bahwa ia telah memiliki aji-aji untuk menolak penyakit. Mungkin juga sebagai syarat semadinya ia berpantang fasilitas medis modern. Kau tahu, hal-hal demikian sangat tak bisa diterangkan akal sehat. Tapi, hal-hal demikian sangat tak bisa diterangkan dengan akal sehat (Utami, 2008: 68).

Perlawanan terhadap dunia paranormal dilakukan oleh Parang Jati dan Yuda dalam kutipan ini. Lelaki yang ditemuinya dengan pakaian kehitam-hitaman bernama Kabur Bin Sasus yang baru selesai semadi. Mereka bahkan menyepelekan sesajen itu dengan memakannya. Perlawanan lagi ditunjukkan oleh mereka ketika Kabur Bin Sasus digigit anjing gila, mereka dengan tegas melawan takhayul yang ada dalam diri Kabur Bin Sasus. Kabur Bin Sasus tidak ingin pergi berobat kepada dokter karena dia tahu bahwa ia akan sembuh dengan sendirinya, tetapi akhirnya dia meninggal juga akibat gigitan anjing gila itu. Akibat kejadian ini, Parang Jati dan Yuda tambah tidak percaya terhadap mistik yang tidak bisa dicerna dengan akal sehat.

Ada yang tersisa dari peristiwa Sajenan itu. Dalam beberapa hari setelahnya, aku mendengar bisik-bisik mengenai hujan yang tercurah sebelum upacara usai. Seorang pawang yang unggul selalu bisa menahan hujan seperti yang ia janjikan. Apa artinya itu, hujan yang muntab sebelum waktunya? Mbok Manyar adalah sang pawang. Seseorang mengehembuskan tuduhan, kekuatan Mbok Manyar sudah berkurang. Ia tak sanggup lagi menahan hujan seperti yang dibutuhkan. Kemudian kutahu, yang berpendapat demikian kebanyakan darin pendukung diam-diam pemuda kupukupu. Mereka kurang menyukai Mbok Manyar karena itu masih berkerabat dengan Kabur Bin Sasus, musuh sang pemuda, dan dianggap mewakili nilai-nilai syirik (Utami, 2008: 159).
Kemampuan Mbok Manyar sebagai pawang hujan diragukan oleh pendukung diamdiam Kupukupu. Bahkan mereka mengatakan Mbok Manyar dan Kabur Bin Sasus mewakili nilai-nilai syirik. Mereka menentang tindakan Sajenan yang dilakukan kedua tokoh yang dihadirkan pengarang memiliki kemampuan yang terkait dengan mistik. Mbok Manyar sebagai pawing hujan dan juru kunci mata air dan Kabur Bin Sasus yang dipercayai sebagai manusia jadi-jadian dan setelah kematiannya dianggap bangkit dari kubur. Hal inilah kemudian mucul perlawanan dari pihak tertentu yang mengecam sikap dan perilaku kedua tokoh ini.

Fantastik yang ditransformasi menurut McHale (1991: 80 - 81) berupa efek fantastik didifusikan melewati penulisan postmodern, hadir dalam bentuk-bentuk yang dipindahkan di dalam teks yang tidak secara formal fantastik.

Manyar menggeleng.'Ini anakku. Namanya Parang Jati," ujarnya sambil tersenyum. Lalu ia serahkan bayi itu ke pelukan Suhubudi.'Peliharalah."

Kemudian Suhubudi menafsirkannya demikian. Seperti ikan pelus keramat yang memelihara mata air di bawah bukit-bukit kapur, bayi ini berasal dari laut. Dalam bahasa Jawa Kuna, parang adalah karang, si batu laut. Jati adalah Sejati ataupun asal. Anak ini adalah parang yang sejati, atau sesuatu yang sejatinya adalah parang. Seperti pelus yang berasal dari laut Selatan, anak itu pun datang dari samudra di mana semayam istana Sang Ratu Segara Kidul. Kerajaan Tasik Wedi. Laut Selatan telah menitipkan bayi ini.

Bahwa seseorang telah meletakkan keranjang berisi bayi di sana, itu sudah pasti bagi orang modern. Dan itu telah niscaya pula bagi Manyar. Sedemikian niscaya, maka itu tak penting lagi baginya. Yang penting bagi dia adalah bahwa kehadiran bayi ini memiliki arti. Dan ia memberikan arti yang pertama. Parang Jati. Tak penting bagi siapa yang membuang anak ini tanpa alasannya. Apakah karena si bocah cacat berjari duabelas. Apakah dia anak tak berayah. Yang demikian itu tak penting (Utami, 2008: 218).

Mbok Manyar menceritakan mengenai riwayat kelahiran Parang Jati kepada Yuda. Parang Jati lahir di bulan Sadha atau dinamakan juga Hapit Kayu. Berdasarkan namanya bahwa 
anak berasal dari laut Selatan seperti ikan pelus yang menjaga mata air di desa itu. Hal ini adalah asumsi pertama mengenai kelahiran Parang Jati yang merupakan dunia paranormal dan supernatural. Akan tetapi, asumsi yang sebelumnya dialihkan Mbok Manyar mendeskripsikan lagi kalau anak ini telah diletakkan oleh seseorang dengan keranjang besi, sangat jelas pada bagian ini pendeskripsian dimensi normal, sehari-hari. Dalam dimensi ini Mbok Manyar menafsirkan kalau anak ini dibuang karena cacat ataukah tidak memiliki ayah.

\section{Fiksi Postmodern X Fakta Historis}

Terdapat ketumpangtindihan antara fiksi postmodern dan fakta historis. Akan tetapi, hal ini sudah berada dalam tahap kelaziman yang akan ditemukan dalam novel hostoris karena tidak selamanya pengarang menggunakan fakta sosial dan tokoh-tokoh yang ada dalam realita dalam novelnya. Hal ini sesuai dengan pendapat McHale (1991: 85) bahwa di daam novel historis sering ditemukan adanya interaksi antara tokohtokoh fiksional yang tentunya kehadiran tokohtokoh fiksional dengan ciri dunia nyata memberikan gelombang kejutan melewati struktur ontologism dunia.

Pulau Jawa dirundung duka, sepanjang kurun waktu Juli 1998 Desember 1998 di Banyuwangi, tak kurang 116 orang yang dituduh sebagai dukun santet,dibunuh oleh pasukan bertopeng, beberapa adalah kyai setempat. Ada beberapa pembunuhan yang bersifat tertutup, misalnya segerombolan massa bertopeng pada malam hari masuk ke rumah salah satu warga, lalu membunuh sasarannya. Namun ada pula yang dilakukan pada siang hari, dengan melibatkan masyarakat, yaitu dengan menuduh target operasi dengan tuduhan sebagai dukun, sehingga masyarakat geram dan turut menyiksa dan membunuh target tersebut. Tidak kurang dari setahun peristiwa ini mereda, kasus penyiksaan dan pembantaian seseorang terkait tuduhan dukun santet juga merebak pada tahun 1999 di Pangandaran. Sampai saat ini, kasus pembunuhan berkedok tuduhan dukun santet ini belum terungkap, provokator peristiwa ini belum ditangkap, dan hal yang menyebabkan amuk massa belum diluruskan (dikutip dari opini Wahyu Ramdhan Wijanarko).
Pada dasarnya, Masyarakat Jawa dikenal sebagai masyarakat yang religius. Perilaku keseharian masyarakat Jawa banyak dipengaruhi oleh alam pikiran yang bersifat spiritual. Dalam kehidupan sehari-hari, masyarakat Jawa memiliki relasi istimewa dengan alam. Pemikiran mengenai fenomena kosmogoni dalam alam pemikiran masyarakat Jawa, yang kemudian melahirkan beberapa tradisi atau ritual yang berkaitan dengan penghormatan terhadap alam tempat hidup mereka (Magnis-Suseno dalam opini Wijanarko).

Kala itu aku tak percaya. Demi mendengarnya pertama kali, aku merasa ia dramatis. Kini, aku tak mau mengulangi apa yang diterangkan Parang Jati kepadaku. Ketika itu, Parang Jati menunjukkan majalah Time yang terbit tiga tahun sebelumnya. Dalam riset klipingku untuk menuliskan kembali kisah ini, kudapatkan artikel yang dulu ia perlihatkan. Dan jika sekarang kita membacanya lagi, kita harus faham bahwa masa itu pers Indonesia belum merdeka penuh. Berita bertanggal terbitan 23 November 1998, setengah tahun saja setelah Sang Jenderal lengser keprabon. Ketika Koran-koran Indonesia masih gugup dengan kemerdekaan yang mereka miliki, majalah asing Time melaporkan peristiwa pembunuhan tersebut secara paling utuh. Setidaknya, penulis bisa member gambaran kepada angkatan sekarang yang barangkali lupa pada apa yang pernah terjadi (Utami, 2008: 421).

Pada novel Bilangan $F u$ ini terjadi pengkontradiksian terhadap kejadian resminya dalam masyarakat Jawa pada saat itu. Dalam novel ini diceritakan mengenai pembunuhan dukun santet oleh pasukan ninja. Parang Jati dalam hal ini tokoh yang aktif dalam kegiatan masyarakat termasuk spiritual yaitu kepercayaan terhadap nenek moyang. Parang Jati yang bercerita bahwa media massa saat itu masih berada dalam tekanan ketika Presiden Soeharto lengser dari jabatannya, meskipun dalam kutipan novel ini tidak dieksplisitkan. Dia juga bercerita bahwa ada keanehan dari pembunuhan msterius ini yang dikira dukun santet itu malah guru ngaji dan penghulu desa. Serta dia juga mengatakan bahwa terdapat penyebaran isu yang salah dan yang bermain di dalam pembunuhan ini adalah strategi informasi oleh beberapa pihak termasuk militer yang berkuasa. 
Pada tahun yang sama, terjadi perubahan politik. Gusdur digulingkan tanpa partumpahan darah. Wakilnya, Megawati Soekarnoputri, menggantikan dia sebagai presiden. Kebetulan atau tidak, pada saat itu perundingan dan tekanan yang dilakukan oleh para pencinta lingkungan, di masyarakat (yang dipelopori Parang Jati) maupun pemerintah, telah berhasil membuat perusahaan penambangan itu menghentikan eksploitasi. Pemerintah juga sedang meninjau usulan untuk menjadikan kawasan itu di bawah konservasi. Perusahaan pun tidak memperpanjang laskar keamanan yang sempat mereka pasang untuk kepentingan mereka. Pasukan Mamon itu dibubarkan dan personilnya dikembalikan ke kampung halaman masingmasing. Maka Farisi terlucuti dari bala tentaranya dan menjadi kupu-kupu lagi (Utami, 2008: 525).

Kemudian diceritakan bahwa Parang Jati telah digelandangi dan dianiaya oleh pendukung Farisi dan masyarakat setempat karena dia dianggap melakukan musyrik di desa Watugung. Hal ini memiliki kaitan menjelang periode kepemimpian Gusdur yang akan digantikan Megawati pada tahun 1999 - 2001, pada tahun 1998 gempar terdengar berita mengena pembunuhan secara misterius terhadap dukun santet. Padahal dalam penceriteraan, Parang Jati adalah mahasiswa hanyalah mahasiswa geologi yang berusaha untuk mnyelematkan Sewugunung dar perusahaan pertambangan dan orang pemanjat tebing. Akan tetapi, dalam penceritaan selanjutnya Parang Jati akhirnya meninggal dunia karena alasan memiliki ilmu hitam. Serta ditemukan bukti bahwa dalam novel ini menceritakan ada tokoh yang diemban amanat untuk menumpas orang-orang yang mendapat tuduhan melakukan perbuatan musyrik karena di balik itu ada unsur kepentingan yang bermain. Ketika terjadi pergantian periode kekuasaan, maka Farisi diceritakan tidak lagi menjadi anggota militer.

Hal ini terkait dengan pemilu Pemilihan Presiden tahun 1999, sarat dimuati oleh intrikintrik politik yang menodai hasil pemilu 1999. Seperti kita ketahui, sampai saat terakhir sebelum hari penghitungan suara, masih terdapat kesimpangsiuran terhadap calon-calon Presiden yang ada. Para pemimpin fraksi melakukan tawar-menawar di belakang pintu tertutup. Kriteria calon Presiden pun tidak ditetapkan secara transparan dan demokratis. Akhirnya calon-calon yang ditetapkan lebih merupakan hasil konsesi politis antara blok-blok politik yang ada di MPR.

Walaupun Partai Demokrasi Indonesia Perjuangan meraih suara terbanyak (dengan perolehan suara sekitar 35 persen), yang diangkat menjadi presiden bukanlah calon dari partai itu, yaitu Megawati Soekarnoputri, melainkan dari Partai Kebangkitan Bangsa, yaitu Abdurrahman Wahid atau Gus Dur (Pada saat itu, Megawati hanya menjadi calon presiden). Hal ini dimungkinkan untuk terjadi karena Pemilu 1999 hanya bertujuan untuk memilih anggota MPR, DPR, dan DPRD, sementara pemilihan presiden dan wakilnya dilakukan oleh anggota MPR.

Beginilah hubungan Suhubudi dengan politik dalam negeri. Sebelumnya ia dekat dengan partai politik Sang Jenderal. Sebuah partai berlambang pohon beringin. Pada masa rusuh dan pergantian kekuasaan, ia menjalin hubungan dengan partai oposisi. Sebuah partai berlambang kepala benteng. Kedua partai itu, partai beringin maupun partai banteng, sama-sama partai nasionalis. Partai berlambang kepala benteng itu dipimpin oleh seorang ibu. Megawati Soekarnoputri namanya. Putri presiden pertama Indonesia. Ketika diadakan pemilihan umum pertama yang demokratis, yaitu setelah Sang Jenderal lengser, partai kepala banteng itu menanglah. Ini terjadi tahun '99. Megawati nyaris menjadi presiden.

Tapi kelompok Islam politik berupaya menjegal dia. Mereka berkampanye bahwa Islam melarang perempuan menjadi pemimpin. Mereka mengajukan Kiai sebagai presiden. Gus Dur panggilannya, seorang ulama yang sangat moderat. Ulama yang mengakrabi kitab putih maupun kitab kuning. Ulama yang percaya diri menjadi Indonesia, bukan menjadi Arab. Ia berperawakan mirip Semar, dan berbicara juga mirip Semar. Dan memang ia kerap dijuluki Semar. Ia pun sangat ambigu, bukan dalam arti jender, melainkan dalam kebiajakan politiknya. Demikian, meskipun partai kepala banteng menang, Gus Dur-lah yang menjadi presiden. Megawati menjadi wakilnya. Ini terjadi tahun 2000 (Utami, 2008: 355).

$\begin{array}{ccccc}\text { Sesuai rekaman aslinya, Gus } & \text { Dur } \\ \text { menjadi presiden } 20 \text { Oktober } 1999 \text { dan }\end{array}$ 
Megawati saat itu menjadi wakilnya. Akan tetapi, kutipan di atas mendeskripsikan bahwa hal ini terjadi tahun 2000. Kemudian diceritakan juga bahwa ayah angkat Parang Jati memiliki hubungan kolega dengan presiden yang berkuasa misalnya Soeharto pada rezim militer, BJ.Habibie, Gusdur, dan Megawati. Yang menjadi sorotan di sini adalah tetap pembunuhan dukun santet di daerah Jawa, pada tahun 1999 yang marak kejadian ini terjadi di Banyuwangi, tetapi dalam novel ini tidak terlalu dirincikan tempat kejadian pembunuhannya. Hanya dideskripsikan bahwa Parang Jati termasuk korban yang mendapat tudingan termasuk beberapa guru ngaji dan penghulu di beberapa wilayah di Jawa.

\section{DAFTAR PUSTAKA}

Agger, Ben. 2009. Teori Sosial Kritis. Yogyakarta: Kreasi Wacana.

McHale, Brian. 1991. Postmodernist Fiction. London and New York:Routledge.

Pujiharto. 2010. Perubahan Puitika dalam Fiksi Indonesia. Yogyakarta: Elmatera.

2002. "Dunia-Dunia Postmodern dalam Novel Larung. Tesis Prasyarat kelulusan S2 Program Studi Sastra Universitas Gadjah Mada.

\section{KESIMPULAN}

Dalam novel ini dipaparkan mengenai spiritualisme kritis dituangkan melalui cerita rakyat serta mengelola begitu banyak cerita ganjil yang terjadi di dalam masyarakat yang didalamnya menganut kemistikan. Sebenarnya di dalam novel ini membahas mengenai tiga hal yang penting yaitu yaitu modernisme, monoteisme, dan militerisme yang bisa menyebabkan kehancuran pada manusia. Sehingga ditemukan dunia-dunia yang dihadirkan pengarang meskipun itu tidak sama persis yang ada dalam realita. Meskipun novel ini lahir di era kontemporer, tetap saja mengupas mengenai dunia rasional dan irasional dan memiliki ciri-ciri kepostmodernan yang mengindikasikan bahwa karya ini bisa ditelaah ke dalam konteks postmodernisme.

Pujihati, Hat. 2009. Novel Enchanted Dalam Kajian Posmodern Brian Mchale. Tesis Prasyarat Kelulusan S2 Program Studi Ssstra Universitas Gadjah Mada.

Ritzer, George. 2009. Teori Sosial Postmodern. Yogyakarta: Kreasi Wacana bekerja sama Juxtapose Research and Publication Study Club.

Strinati, Dominic. 2010. Popular Culture. Yogyakarta: Ar-Ruzz Media.

Utami, Ayu. 2008. Bilangan Fu. Jakarta: Kepustakaan Populer Gramedia. 